Sultan Qaboos University Journal of Arts \& Social Sciences
جامعة السلطان قابوس

مجلة الآداب والعلوم الاجتمأعية

\title{
Restrictive Conditions for Free Uses of Copyrighted Materials under Omani Law and Their Implications for Users of Copyrighted Materials*
}

\begin{tabular}{c}
\hline Saleh Hamed Albarashdi \\
\hline Assistant Professor, College of Law \\
Sultan Qaboos University \\
sinaw814@squ.edu.om
\end{tabular}

Saleh Hamed Albarashdi

Sultan Qaboos University
sinaw814@squ.edu.om 


\title{
Restrictive Conditions for Free Uses of Copyrighted Materials under Omani Law and Their Implications for Users' of Copyrighted Materials*
}

\author{
Muhammad Masum Billah and Saleh Hamed Albarashdi
}

\section{Abstract:}

The Omani Copyright and Neighboring Rights Law of 2008 contains a list of exceptions to the exclusive rights of copyright holders. These exceptions allow people to copy and use copyrighted materials in certain cases without paying any fees or obtaining any permission from the copyright holders. The exceptions cover free uses for purposes like teaching, education, quotation in another work, dissemination of news etc. However, the Omani Copyright and Neighboring Rights Law puts many conditions for such free uses. Some of these conditions mirror similar conditions under the Berne Convention and other copyright conventions to which Oman is a party. Other conditions under Omani law are more restrictive than those that appear under international conventions. These additional conditions restrict the scope of free uses of copyrighted materials in Oman. Yet, some countries like the USA and Canada, despite their being parties to the same international conventions, have much wider exceptions under their national legislation. The paper, therefore, recommends that Oman should follow the legislative approach of those countries in order to widen the scope of copyright exceptions for the benefits of users of copyrighted materials in Oman.

Keywords: Copyrights Law; Fair use; Teaching Purposes.

\section{شروط الاستخدام العادل (المجاني) للمصنفات المحمية وفقا لقانون المؤلف العماني وأثره على مستخدميها}

محمد معصوم بالله، وصالح بن حمد البراشدي

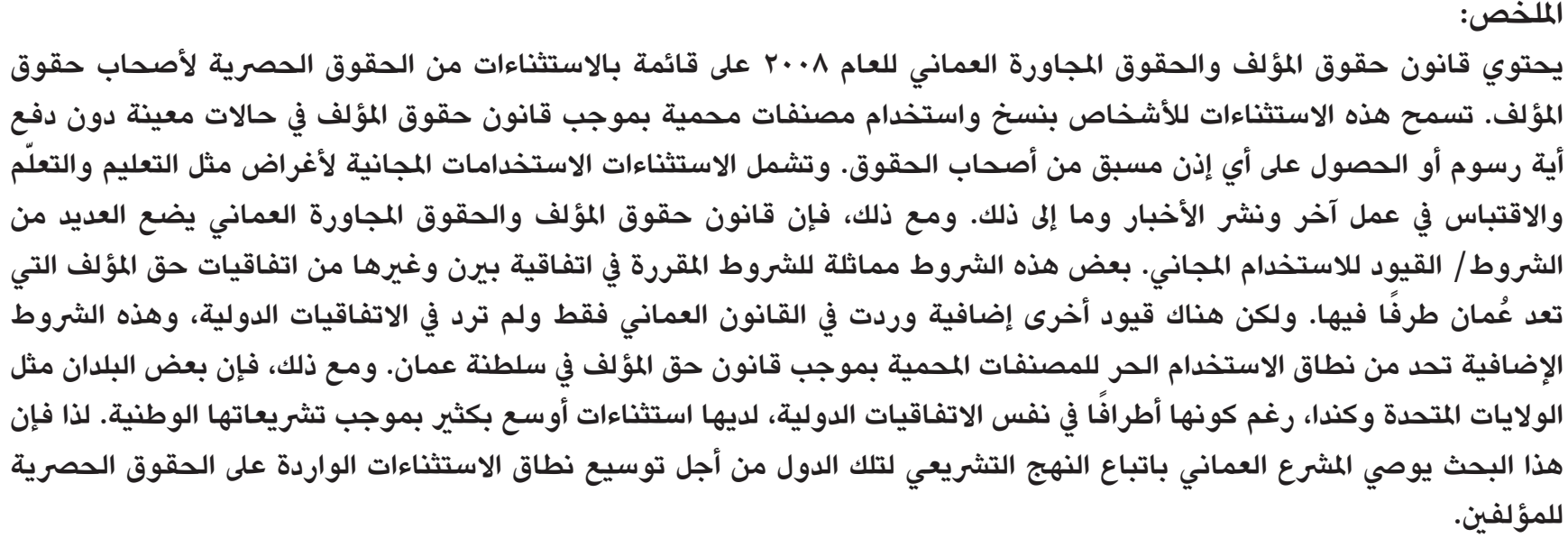




\section{Introduction}

Like copyright laws of most countries in the world, the Copyright and Neighboring Rights Law of Oman issued in 2008 by a Royal Decree number 65/ 2008 contains a list of exceptions to the exclusive rights of copyright holders. Under these exceptions, people can use and copy copyrighted materials for certain purposes without permission from their copyright holders when such permission would otherwise be required in the absence of these exceptions. To some extent, these exceptions balance the public interests of users against the private interests of copyright owners. The exceptions cover free uses and copying for some laudable purposes such as teaching, education, quotation in another work, dissemination of news etc. However, the scope of free uses under the Copyright Law of Oman is heavily restricted through many conditions. Some of these conditions are general and thus apply to all the enumerated exceptions. There are separate sets of conditions applicable to individual group of exceptions. Some of the conditions under Omani law mirror the conditions found in the Berne Convention and other copyright related treaties (TRIPS Agreement, WCT, and WIPO Performance and Phonograms Treaty) to which Oman is a party. It is worth noting that Oman became a party to the Berne Convention on April 14, 1999. However, Omani law contains some conditions that are more stringent than what appears under the above-mentioned copyright treaties. This has the effect of narrowing the scope of free uses for users of copyrighted materials in Oman. Yet, some countries, despite their being parties to the same international convention, have much wider exceptions under their national legislation. Unless it would be contrary to Oman's international obligations under the copyright treaties to do so, Oman should follow the legislative approach of these countries in order to widen the scope of the free uses of copyrighted materials.

\section{Free Uses of Copyrighted Materials under Omani Law}

Before we analyze the conditions of free uses of copyrighted materials under Omani law, we will briefly discuss the list of free uses under the Omani law. There are seven categories of free uses allowed under the Copyright Law of Oman (Article 20 of Omani Copyright Law). Using part of a copyrighted work as quotation is the first type of free uses mentioned under Omani law. The second category of free use covers the use of a copyrighted work within family or in an educational institution for face-to-face teaching and learning. The third category includes free reproduction of certain copyrighted materials by public libraries or non- commercial educational and documentation centers either for the purpose of private study and research of an individual or for the purpose of preservation of a copy against the loss of the original copy. The fourth type of free uses is to reproduce, broadcast, or to make available to the public certain copyrighted materials by the press and media. These copyrighted materials include articles published in periodicals or newspapers, or materials broadcast in other media on current economic, political, or religious issues. The fifth type of free and permissible use is the reproduction of a computer program from a copy by the legitimate owner of the copy. The sixth category covers public performance of dramatic and musical works either for religious purpose or for face-to-face teaching and learning in educational institutions. The seventh and the last category of free use of copyrighted materials is to make a temporary copy of a broadcast program by the broadcasting organization.

\section{Conditions for Free Uses under Omani Law} Article 20 of the Copyright Law of Oman, which enumerates the list of free uses, contains certain conditions for such uses. Some of these conditions are general and are applicable to all of the free use categories. There are also specific conditions for each category of free uses. We will analyze both groups of conditions under Omani law in light of the Berne Convention and other copyrighted related conventions to which Oman is a party. Our analysis will show that Omani copyright law does not simply meet the conditions imposed by those treaties but goes beyond what is required under the treaties. Omani copyright law thus enhances the ever-increasing protection for authors, artists and other copyright holders and reduces further the already shrunken rights of copyright users.

\section{A. General Conditions}

All free uses of copyrighted materials under Omani law are subject to three conditions. First, the source of the work and the name of the author, where available, must be mentioned. Second, the use must not conflict with the normal exploitation of the work. Third, the use must not unreasonably prejudice the legitimate interest of copyright owners. While it is easy to understand and comply with the first condition of acknowledgement of source and authors, the last two conditions are vague and difficult to interpret and to apply to actual cases. The first condition reflects similar condition under article 10(3) of the Berne Convention. The last two conditions have their origin in the three-step test of the Berne Convention under its article 9(2) with regard to the free use exceptions to 
the copyright holders' exclusive right of reproduction. The three steps or conditions under the test are: a) the exceptions are only for special cases; b) they must not interfere with the normal exploitation of the work; and c) they must not unreasonably prejudice with the legitimate interests of the author (Billah and Albarashdi, 2018:433-434, 440). The interpretation of three-step test is cumulative i.e., the combined effect of all the steps should be taken into consideration to justify the validity of an exception to the exclusive right of reproduction (Okediji, 2000:125-126).

While under article 9(2) of the Berne Convention the three-step test applies only with regard to the exception of authors' exclusive right of reproduction, Oman made the test applicable to all free use exceptions whether they involve reproduction or other rights of copyright owners. For some of the free use categories, the test may create more hurdles than those imposed by the Berne Convention. For example, free use of copyright materials for teaching is permissible under article $10(2)$ of the Berne Convention and is not subject to the three-step test of article 9(2). Yet, under article 20 of Copyright Law of Oman, all free uses including use of copyrighted materials for teaching would be subject to the test. Similarly, quoting from a copyrighted material under article 10(1) of the Berne Convention does not require satisfying the three-step test, but does so under Omani law. Also, reproducing or broadcasting of articles on a topic of current political, economic or religious issues published in newspapers or broadcast in other media is allowed under article 10bis(1) of the Berne Convention without the need to meet the three-step test, unlike the case for similar situation under article 20 of Omani Copyright Law.

As the three-step test under the Berne Convention applies to copyright holders' exclusive right of reproduction, one may wonder whether there can be uses of copyrighted materials that do not involve 'reproduction'. The answer is definitely in the affirmative. Reproduction can occur broadly in two forms: 1) making copies (e.g., photocopying, and videotaping); and 2) making phonorecords (e.g., duplication of sound-recording and taping off the air) (US Copyright Office, 2014). There are some uses of copyrighted materials without reproduction e.g., public performance and creation of a derivative work from a copyrighted work. A related question is: if an enumerated use under the Berne Convention (e.g., quotation or illustration in teaching) requires reproduction, should the exception be automatically subject to the three-step test? The answer is not necessarily in the affirmative. Even if permissible use of copyrighted materials under the Berne Convention would require reproduction, such reproduction should not be subject to the three-step test of article 9(2) of the Berne Convention. This is due to a general rule of interpretation that a specific provision would prevail over a general one in case of any conflict (Edmond v. United States, 1996:657). Only if a reproduction is for a use not specifically addressed in the Berne Convention, the reproduction would fall under article 9(2) of the convention and has to satisfy the requirements of the three-step test.

A probable reason Omani Copyright Law included the last two steps of the three-step test for all free use exceptions seems to be the adoption of the test in the TRIPS Agreement for all exceptions to the rights of copyright holders.The TRIPS Agreement automatically applies to Oman as the latter is a member of the WTO. Articles 13, 17, 26(2) and 30 of the TRIPS Agreement incorporated the three-step test for any exception to intellectual property rights into the laws on copyright, trademark, industrial design, and patent respectively (Wright, 2009:604). In this regard, the style of Omani Copyright Law is similar to the one adopted under article 13 of the TRIPS Agreement. Article 13 adopts the three-step test for all exceptions to the rights of copyright holders and not just to the right of reproduction (Gervais, 2005:16, and Goldstein, 2001:364). Similarly, article 10 of WIPO Copyright Treaty (WCT) and article 16 of the WIPO Performances and Phonograms Treaty (WPPT) adopted the test for their respective exceptions.

The approach of Omani law is similar also to that of most civil law countries. The courts in most civil law countries have to decide the validity of an exception to the rights of a copyright holder in light of the last two steps of the three-step test of the Berne Convention (Band and Gerafi, 2015). The E.C. Copyright in the Information Society Directive of 2001 also followed the same approach. Article 5 of the Directive lists one mandatory exception for temporary copy in the context of digital communication and twentyone optional exceptions (Goldstein and Hugenholtz, 2010:kn\363). All these exceptions are subject to the three-step test (Gervais, 2005:19-21). The national legislation of some common law countries also include the three-step test in their copyright exceptions. Again, this is probably to ensure the compliance of national laws with a country's obligations under the TRIPS Agreement (Gendreau, 2011:322). For example, the Australian Copyright Act, which includes the test in its provisions governing the exceptions, expressly states that the steps in the test or the words of the test such as 'special case', 'conflict with a normal exploitation', and 'unreasonably prejudice the legitimate interests' have the same meaning as that in article 13 of the 
TRIPS Agreement.

The way article 20 of Omani Copyright Law is designed, Oman appears to have met its obligations under the TRIPS Agreement, WCT, and Berne Convention, Oman being a party to all three conventions. However, the design of the provisions has inadvertently narrowed the scope of free uses by Omani citizens of copyrighted materials in the enumerated circumstances under article 20 of the Copyright Law. Inclusion of the test in the national legislation for all free use exceptions has the effect of narrowing the exceptions countries are permitted to make in their national legislation. Not only the exception to the authors' exclusive rights of reproduction but also any other exception to any other rights of authors (e.g., public performance) becomes subject to the three-step test (Okediji, 2000).

As stated above, the inclusion of the three-step test for all copyright exceptions under some international conventions such as the TRIPS Agreement and the WCT brings more conditions to the exceptions than the conditions mentioned in the Berne Convention and thus leads to more protection for the interests of copyright holders. Providing more protection to the rights of copyright holders through other conventions appears to be permissible under the Berne Convention. Article 20 of the Berne Convention allows the countries of the Union to make agreements that may grant authors more protection than the minimum protection granted under the Berne Convention. In other words, imposing more restrictions on copyright exceptions through the adoption of three-step test under article 13 of the TRIPS Agreement that increases the protection for authors is permissible under article 20 of the Berne Convention. However, there appears to be some internal conflict in the TRIPS Agreement as it states in article 9(1) that the agreement incorporates articles 1 to 21 of the Berne Convention. Such incorporation would require that the TRIPS Agreement make no changes to the laws stated under article 1 through article 21 of the Berne Convention. Yet, the inclusion of the three-step test under article 13 of the TRIPS Agreement makes the copyright exceptions under articles 2, 9, 10, and 11 of the Berne Convention more restrictive than would be the case under the Berne Convention itself.

Alternatively, it can be argued that the TRIPS Agreement did not change the copyright exceptions under the Berne Convention and the various conditions under the convention. In other words, an exception under the Berne Convention not otherwise subject to its three-step test would not become so now due to the inclusion of the test in the TRIPS Agreement (Geiger et al, 2014:588). If, on the other hand, an exception is mentioned only in the TRIPS
Agreement (e.g., rental right in articles 11 and 14.4) but not in the Berne Convention, the exception would be subject to the three-step test (Geiger et al, p. 588). If we accept this view, the TRIPS Agreement would neither increase nor reduce the scope of the exceptions available under the Berne Convention. The drafters of the WCT clearly indicated this effect when they transposed the three-step test of the Berne Convention into article 10 of the WCT. In light of this reading, Omani Copyright Law also should not impose greater restrictions than those imposed by the Berne Convention. In case of any apparent conflict between the Berne Convention and other conventions related to copyright, the former should prevail as implicitly indicated in article 9(1) of the TRIPS Agreement as well as in article 10 of the WCT.

\section{B. Specific Conditions}

In addition to the general conditions discussed above, there are specific conditions for each of the enumerated free use categories under article 20 of the Omani Copyright Law. Some of these conditions appear in more than one category of free uses. For example, the condition of 'fairness' with regard to the quantity of the copyrighted material which can be freely used is mentioned in the categories of quotation, use in the family, and face-to-face teaching. Similarly, the prohibition of obtaining any direct and indirect financial gain from a use is a specific condition both in face-to-face teaching and in the reproduction of a work by a library either for private study and research or for perseveration of the original. With this brief introduction of the specific conditions, we now turn our attention to the analysis of these conditions for each separate category of free uses.

\section{Quotation}

For the first category of free uses i.e., quotation, there are several conditions under Omani Copyright Law. First, the work from which a part is taken as a quotation must be lawfully made available. Second, the purpose of the quotation has to be for clarification, explanation, or criticism of the work. Third, the amount quoted must not exceed what is necessary to achieve the intended purpose. These conditions mostly reflect the requirements under article 10(1) of the Berne Convention. However, unlike Omani law, article 10(1) of the convention does not limit the use of quotation for any specific purpose. Thus, quoting part of a work for any purpose is permissible under the Berne Convention as long as the amount taken is within the limit of fair practice and the work is published. In this regard, the Omani law appears to be narrower than the Berne Convention as the former 
permits quotation only for some specific purposes. If the purpose of the quotation is something other than the ones mentioned, the free use exception under the Omani law may not cover such quotation. For example, someone may take a paragraph from a book as a quotation simply for its literary beauty. Such quotation may be neither for clarification nor for criticism. This again shows that Omani law imposes more conditions than those mentioned under the Berne Convention and restricts the rights of the users of copyrighted materials.

Quotation is one of the few mandatory exceptions under the Berne Convention (Ricketson, 1987:489). As for most of the other exceptions, the Berne Convention left it to the discretion of the countries of the Union whether to include the exceptions in their national legislation. It is worth repetition that the general condition under article 20 of the Copyright Law of Oman has already subjected quotation together with all other exceptions to the last two steps of the threestep test of the Berne Convention. On the other hand, free use of copyrighted materials for quotation under article 10(1) of the Berne Convention is not subject to the three-step test. Professor Ricketson, however, suggests that the requirement that a quotation be 'compatible with fair practice' under article 10(1) carry the same meaning as that of the last two steps of the three-step test. In other words, for a quotation to be 'compatible with fair practice' the quotation must not conflict with the normal exploitation of the work and must not unreasonably prejudice the legitimate interest of the author (Ricketson, 1987:492). The legislative history of the provision, however, does not clearly support this view (Ricketson, 1987:487).

\section{Use within family and educational institutions}

The second type of free use exception under Omani law is the use of a copyrighted work within family or in an educational institution. There are also several conditions mentioned for such use. First, in the case of education and teaching, the use must be for clarification and has to be only in face-to-face teaching environment. Second, in both family and institutional use, the amount of work used must be limited to an amount justified for the purpose. Third, there must not be any direct and indirect financial gain from such use.

The Berne Convention does not mention free use exception of copyrighted material within family. Inclusion of this exception in the Copyright Law of Oman is an improvement over the Berne Convention. The probable justification for the exception lies in the practical difficulty of enforcing copyright law against any infringement in such context.
As for the free use exception for teaching and education, the Berne Convention specifically covers the exception. The scope of the exception is, however, much broader under the Berne Convention than under the Omani law. First, unlike the Omani law, the Berne Convention does not subject the exception to the three-step test. Since the convention deals with the teaching exception separately under article 10(2), such use whether through reproduction or other means should not be subject to the provisions of article 9(2) especially to its three-step test (Ricketson, 1987:487). The only condition attached for such use under the Berne Convention is that the use must be compatible with fair practice. Second, article 10(2) of the convention allows the countries of the Union to permit utilization of copyrighted materials for teaching in very broad terms. On the other hand, the exception under Omani law is available only for faceto-face teaching in an educational institution. Thus, it appears that free use of copyrighted materials for teaching and education under Omani law would not cover distant education as well teaching outside a formal educational institution (e.g., community learning) whether face-to-face or not. There is no clear indication in the convention to exclude distant education or correspondence courses (Ricketson, 1987:498). Third, the Berne Convention does not stipulate that such use be without any direct and indirect financial benefits. If enforced strictly, these additional conditions under the Omani Copyright Law would restrict the free utilization of copyrighted materials for education and teaching beyond the limits anticipated under the Berne Convention. This may generate some negative effects on education in Omani society. These conditions under the Omani law made the free use for education and research so narrow that a study by the WIPO on copyright exception for education in Arab countries did not consider the exception under Omani law to be useful at all for education and research (Nabhan, 2009:13). Finally, the education and teaching exception is not subject to the three-step test under the Berne Convention. Here again, Professor Ricketson thinks the wording 'compatible with fair practice' under article 10(2) of the convention imports the conditions of three-step test under article 9(2) to this exception (Ricketson, 1987:498).

\section{Reproduction by libraries}

Reproduction of copyrighted materials by public libraries and non-commercial educational and documentation centers is the third type of free use allowed under the Omani law. Here again there are certain additional conditions attached to such use. 
First, such reproduction must be either to facilitate the use of a work by a natural person for his or her private study and research, or to preserve a copy of the work when its replacement would not be possible if the original is lost. Second, there must not be any direct or indirect financial gain from such reproduction. Third, reproduction for the purpose of private study and research must be limited to a short work or to a published article. Fourth, free use for private study and research is permissible only if there is no collective license arrangement available (Article 20(3)(a) of the Copyright Law of Oman). Fifth, as for the reproduction for the purpose of preservation of the original, a library can utilize this exception only when it is impossible to obtain a substitute copy of the work (Article 20(3)(b) of the Copyright Law of Oman). On the positive note, Omani Copyright Law, like the copyright laws of many other nations, specifically covers the copyright exception for education and research. This is because of the important role education and research play in the economic and social development of a nation. This exception covers the right of reproduction for students and researchers. While students and researchers may benefit from other exceptions to copyright (e.g., quotation or illustration in teaching), reproduction of copyrighted materials is the primary means through which they can reap the greatest benefit from copyright exception for their education and research. Copyright laws around the world including copyright law of Oman allow reproduction of copyrighted materials for education and research. However, such reproduction is not without any limits or conditions. Some of the conditions for such copying under Omani law are reasonable and appear in national legislation of other countries. For example, limiting the amount of copying to a short work or to a published article is an acceptable limit. Similarly, allowing a library to copy only when no substitute copy is available seems to be a reasonable condition.

Some of the conditions under Omani law, however, are more restrictive than those of the Berne Convention and national laws of many other countries. For example, the fourth condition under Omani law i.e., the non-availability of licensing arrangement for such copying seems to be much more restrictive than is the case under the Berne Convention. If license arrangement is available in Oman, it seems that there cannot be any free copying by public libraries for students and researchers. In contrast, the Supreme Court of Canada held that availability of license should not be relevant factor in determining 'fair dealing', the Canadian equivalent of free use exception ( $\mathrm{CCH}$ Canadian Ltd. v. Law Society of
Upper Canada, 2004:373-374). Otherwise, the court reasoned, the scope of copyright monopoly would be unreasonably widened at the expense of copyright users' rights. Some earlier American cases, however, held that the availability of license might make a use (i.e., copying without license fees) less fair even though such availability would not be a decisive factor in determining 'fair use' (Cambridge University Press v. Patton, 1994), the American copyright exception for free use. By making the non-availability of licensing arrangement as a condition in case of reproduction for private study and research, Omani law prohibits any such reproduction in the presence of a licensing system.

In addition, the second condition of no direct and indirect financial gain goes beyond the limit imposed by the Berne Convention and other copyright-related conventions. There is no mention of this condition in any of the international conventions related to copyrights. Under American Copyright Act of 1976, commerciality of a use may be a factor in determining whether a use is fair or not. Absence of commercial benefit is not a condition either under American fair use doctrine or under Canadian fair dealing exception. A use may be fair even though the user obtains some financial gain from the use. For example, the Supreme Court of Canada held in CCH Canadian Ltd. v. Law Society of Upper Canada (2004), that the use of copyrighted materials by lawyers in their profitable practice would be still covered by research exception under the fair dealing provision of the Canadian Copyright Act of 1985. Similarly, the American courts also held that profit motive would not be the decisive factor in determining whether the use was fair or not (New York Times Co. v. Roxbury Data Interface, Inc, 1977:221). Under Omani law, on the other hand, libraries or other educational institutions cannot make a free copy of a copyrighted work for a student or a researcher when the student or researcher would obtain some direct or indirect financial gain from their use of a copyrighted material. It is not clear what would be considered as 'indirect' financial gain. Is the potential future earning of a student due to the study of books borrowed from libraries considered as 'indirect' financial gain?

\section{Reproduction and other use by press and media}

The fourth type of free use allows the press and media to reproduce, broadcast, or make available certain copyrighted works to the public. These copyrighted works are articles published in periodicals and newspapers, or broadcast in other media on current economic, political, or religious issues. This provision 
mirrors article 10bis(1) of the Berne Convention. The condition for such free use is that a particular work falling under this category did not expressly reserve such use for its copyright owner at the time of publication. In other words, if any of the abovementioned copyrighted work expressly prohibits a particular use (e.g., copying or broadcasting), the use would not fall under the exception (WIPO, 1978). As copyright attaches to a work automatically without any formalities, works on current economic, political, or religious issues would usually have copyright. Yet, to prevent free use of such works by press and news media such works must have an express indication prohibiting their free use by the press and news media (UNESCO and WIPO, 1976:11). However, even though one cannot make exact copying in case of such prohibition or reservation, one can use the information or the facts in such publication because there is no copyright in facts and information.

Although this exception under Omani law does not contain any additional conditions over those mentioned in the Berne Convention, the exception is still subject to the three general conditions mentioned in the preamble of article 20 of Omani copyright law. Only the first general condition i.e., acknowledgement of source and the name of the author is a condition for this exception under the Berne Convention. The other two general conditions (no conflict with the normal exploitation and no prejudice with the legitimate interests of author) are additional and may reduce the usefulness of this exception for Omani press and news media. Under the Berne Convention, the press and news media can use any copyrighted works on current economic, political, and religious issues regardless of the effect of the use on economic interest of the copyright holders. In contrast, under Omani law if the use affects the economic exploitation of the works, the exception would not cover the free use of the works.

\section{Copying a computer program}

The fifth category of free uses allows the legitimate owner of the copy of a computer program to make further copies. The main condition here is that such reproduction is necessary either to use or adapt the program in a different computer or computer language, or to save it for future use by the owner in case the original is lost or damaged. As this exception relates to computer software, it naturally did not appear in the Berne Convention. The latest amendment to the convention was in September 28, 1979, a time when computer technology was not popular or affordable to ordinary members of the public. The Berne Convention, in fact, has no mention about computer program. The TRIPS Agreement and WIPO Copyright Treaty, however, recognize computer programs as literary work under the Berne Convention.

The approach of Omani law with regard to this exception is similar to the approach in copyright legislation of other countries. For example, section 36.1 of Canadian Copyright Act allows the owner or the licensee of a computer program to reproduce the program for personal use with a particular computer or for backup in case the original is lost or destroyed as long as the person remains the owner or licensee of the copy. Similarly, §117(a) of the American Copyright Act allows the purchaser of a computer program to make a copy of the program when doing so is essential for utilization of the program or for archival purpose. If the owner ceases to be the owner of the purchased copy, he must destroy any copy made for archival purpose $(\S 117(a)(2)$ of US Copyright Act of 1976).

Even though not mentioned in the Berne Convention, reproduction of computer program for the abovementioned purposes would be permissible under general 'reproduction' exception of article 9(2) of the convention. Reproduction in such case would meet the three-step test of the article. First, national legislation allows such reproduction in 'special cases.' Special cases here may include copying a computer program to adapt it for use in a particular device. Second, such reproduction would not conflict with the normal exploitation of the work as the copyright holder has already received the price of the copy from the purchaser. Additional copies made by the purchaser are for her personal use and thus do not deprive the copyright holder of revenues from other prospective users. Third, such reproduction does not seem to cause unreasonable prejudice with any other legitimate interests of copyright holders. As discussed earlier, the general conditions under article 20 of Omani law covers the last two conditions of the three-step test of the Berne Convention. Thus, only with regard to this exception, the Omani law does not impose any additional conditions over those in the Berne Convention or in other copyright treaties.

\section{Public performance in certain cases}

The sixth type of free and permissible use of copyrighted material is the public performance of dramatic or musical works either for religious purpose or for face-to-face teaching and learning in educational institutions. In both cases, the performance must be non-commercial in nature. This exception also does not have a direct basis in the Berne Convention or in any other conventions related to copyright. However, similar exception appears in national legislation of some countries including the US Copyright Act and 
Canadian Copyright Act. For example, s. 29.5 of Canadian Act covers similar exception for teaching and learning and not for religious purpose. Like Omani law, Canadian law too stipulates that such performance in an educational institution be without any financial gain. American law, however, does not contain any such stipulation (section 110(1) and (3) of the US Copyright Act of 1976).

It is noteworthy here that the Berne Convention gives the copyright holder the exclusive right to authorize public performance of dramatic, musical, or dramatico-musical works. The teaching exception under article 10(2) of the convention allows the use of 'literary and artistic works' as illustration for teaching in a publication, broadcast, or audio-visual recordings. The words 'dramatic, musical, or dramatico-musical works' under the above exception of Omani law may fall under 'literary and artistic works' of article 10(2) of the convention. The words 'illustration in publication, broadcast ...' under article 10(2), however, do not seem to cover 'public performance' of such works. However, looking at the spirit of the Berne Convention and the specific exception for illustration in teaching, the exception of public performance of the above works under national legislation of various countries, especially when used for teaching, does not seem to go beyond the permissible limits of the Berne Convention.

\section{Copying by a broadcasting organization}

The seventh and the last category of free uses of copyrighted materials is to make a temporary copy of a broadcast program by the broadcasting organization. The basis of this provision is section 8 of the Tunis Model Law on Copyright for Developing Countries. The provision seems to be inspired by article 11 bis(3) of the Berne Convention. Article 11bis(3) allows the countries of the Union to have laws regulating the ephemeral recording of broadcast programs by the broadcast organizations or to keep a copy of the programs in the archive due to their exceptional nature.

The conditions Omani law imposes for this category of free use are that the broadcasting organization had the right to broadcast the program and that the broadcasting organization would destroy the program after six months from its making unless the organization wants to keep a copy for archival purpose. These conditions are similar to the ones suggested in the Tunis Model Law or the Berne Convention. However, the Berne Convention does not subject this exception to the three-step test. Yet, if we consider the recording by a broadcasting organization as a form of reproduction, the exception may fall under article 9(2) of the convention and may be subject to its three-step test. Under article 9(2), any exception to the author's exclusive right of reproduction is subject to the threestep test. On the other hand, if we consider this exception covered by article 11 bis(3), it is a separate exception and thus is not subject to the three-step test. As argued earlier, if a separately numerated exception requires reproduction for its utilization, the exception should not be subject to the three-step test of article 9(2). A specific provision such as article 11 bis(3) should have priority over a general provision (e.g., article 9(2)) in case of any conflict between them (Edmond v. United States, 1996, at 657).

Even if such recording has to satisfy the three-step test, the recording would easily meet the conditions of the test. Such recording is made for archival purpose i.e., for a special case. Such recording would not conflict with the normal exploitation of the work. Conflict in this context would occur in case of rebroadcasting. The right to authorize rebroadcasting of a previously broadcast program is an exclusive right of the copyright holder. Thus, if the broadcasting organization wants to rebroadcast the program, the organization would have to take permission from the copyright holder. Finally, it is hard to see how such archiving would prejudice any legitimate interests of the author. In fact, the preservation of the program by a broadcasting organization may benefit the copyright holder in case of any loss or damage of the original copy held by its copyright holder.

\section{Implications of the Restrictive Conditions to Free Uses}

While the purpose of the conditions attached to various free uses of copyrighted materials under Omani copyright law is to ensure Oman's compliance with the Berne Convention and other copyright related treaties, the conditions under Omani law are more onerous than those appeared in the corresponding international conventions. These conditions have narrowed the scope of free uses of copyrighted materials for Omani users. The conditions made the free use exceptions under Omani law so narrow that a study by WIPO on copyright exception for education in Arab countries did not find these exceptions under Omani law helpful at all for education and research (Nabhan, 2009:13). As a minimum, Oman should reproduce the provisions of the Berne Convention in its copyright legislation with minor modifications of the wording necessary to transpose the exceptions from the convention to its national legislation. Alternatively, Oman can also follow the approach of American fair use doctrine which appears to be broader than the copyright exceptions under the 
TRIPS Agreement because of the latter's adoption of the three-step test for all exceptions (Okediji, 2009, pp. 119-120). The American fair use doctrine simply provides some factors to determine the permissibility of a copyright exception. There are four nonexhaustive factors mentioned under the US Copyright Law. They are the purpose of the use, the nature of the copyrighted work, the amount copied, and the effect of use on the potential market of the work (§107 of US Copyright Act of 1976). Any use could be fair and thus free as long as the factors weigh more favorably for fair use than for infringement. While American fair use doctrine is a bit vague and thus may occasionally seem uncertain, it provides great flexibility for applying the doctrine to any type of use regardless of the change in technology.

Like Oman, Canada also has an enumerated list of copyright exceptions. Despite that, the Supreme Court of Canada adopted similar factors as those mentioned under US Copyright Law. In its 2004 decision, CCH Canadian Ltd. v. Law Society of Upper Canada [2004] 1 SCR 339, 342, 366, the Supreme Court of Canada provided six factors to determine whether a particular use would fall under Canadian 'fair dealing' exception. The factors are: (1) the purpose of the dealing; (2) the character of the dealing; (3) the amount of the dealing; (4) the nature of the work; (5) available alternatives to the dealing; and (6) the effect of the dealing on the work. Like the factors under $\$ 107$ of American Copyright Act, the six factors used by the Supreme Court of Canada are also non-exhaustive (CCH Canadian Ltd. v Law Society of Upper Canada, 2004 SCC 15, [2004] 1 SCR 339, 369). Instead of two groups of conditions, general and specific, Oman can include similar factors under its copyright law in order to determine the permissibility of free use in a specific situation.

\section{Conclusion}

Overall, Oman is a nation more on the side of importing copyrighted materials than exporting them. As such, Omani law should be more favorable to the users' rights than those of copyright holders. Of course, Oman is a party to many copyright conventions and thus has international obligations to protect the rights of copyright holders. Therefore, the modification of Omani law to favor users' rights must be within the limits imposed by the international conventions on copyright to which Oman is a party. We suggest that Omani law in designing its copyright exceptions should simply use the conditions mentioned under the Berne Convention. As discussed earlier, the conditions imposed by the TRIPS Agreement appear to be more stringent than those of the Berne Convention. The
Berne Convention, however, is the main copyright convention. The TRIPS Agreement and the WCT do not intend to modify the Berne Convention. Thus, when it comes to copyright exceptions a country's adherence to the Berne Convention should suffice to meet its international obligations under all the above-mentioned conventions related to copyright. Alternatively, Oman could follow the approach of American copyright legislation by adopting a doctrine similar to 'fair use' together with its flexible criteria.

\section{Endnotes}

The preamble to article 20 reads, "Subject to the moral copyrights, stipulated under this law, the following uses of works shall be lawful even without the consent of the author provided that the source and the name of the author are mentioned if listed in the work, and provided that a free use shall not be allowed if the use conflicts with the normal exploitation of the work, performance, or phonogram or unreasonably prejudices the legitimate interests of the author, performer, or producer of phonograms."

In this regard, the difference between Omani law and the Berne Convention is that the latter imposes this condition mainly with regard to the quotation and teaching exceptions while Omani law makes it a condition for all categories of free use. However, if the provisions of Omani law intend to import the right of 'paternity' (i.e., the right to be recognized as the author) into all exceptions, then there may not appear any difference between Omani law and the convention as article 6 bis of the convention recognizes such moral right. Article 6bis applies to all exceptions. See the Report on the Work of Main Committee in Records of the Intellectual Property Conference of Stockholm: June 11 to July 14, 1967 (WIPO, Geneva: 1971) at 1165.

\section{References}

Agreement on Trade-Related Aspects of Intellectual Property Rights, April 15, 1994, Marrakesh Agreement Establishing the World Trade Organization, Annex 1C, Legal Instruments-Results of the Uruguay Round vol. 3, 1869 U.N.T.S. 299, (1994) 33 I.L.M. 81 [cited as TRIPS Agreement].

Band, J., and Gerafi, J. (2015), The Fair Use/Fair Dealing Handbook, (last access date: August 14, 2018), retrieved from http://infojustice.org/wp-content/ uploads/2015/03/fair-use-handbook-march-2015.pdf

Berne Convention for the Protection of Literary and Artistic Works, Sept. 9, 1886, as last revised in July 24, 1971, amended Oct. 2, 1979, S. Treaty Doc. No. 99-27, 
828 U.N.T.S. 221 [cited as Berne Convention].

Billah, M. M., and Albarashdi, S. (2018), Fair or Free Use of Copyrighted Materials in Education and Research and the Limit of Such Use, Chicago-Kent Journal of Intellectual Property, 17, 422-448.

Copyright Act of 1976, 17 U.S.C. §§101-808 (1976) (USA).

Copyright Act, R.S.C., 1985, c. C-42 (Canada).

Copyright and Neighboring Rights Law, Royal Decree 65/2008 (Oman) [cited as Copyright Law of Oman].

Directive 2001/29/EC of the European Parliament and of the Council of 22 May 2001 on the Harmonisation of Certain Aspects of Copyright and Related Rights in the Information Society [cited as EC Directive].

Geiger, C., Gervais, D., and Senftleben, M. (2014), The Three-Step Test Revisited: How to Use the Test's Flexibility in National Copyright Law, American University International Law Review 29, 581-626.

Gendreau, Y. (2011), Intellectual Property Colloquium Series: Canada and the Three-Step Test: A Step in Which Direction?, Marquette Intellectual Property Law Review, 15, 309-323.

Gervais, D. J. (2005), Towards a New Core International Copyright Norm: The Reverse Three-Step Test, Marquette Intellectual Property Law Review, 9, 1-35.

Goldstein, P., and Hugenholtz, P. B (2010) (2nd ed.), International Copyright: Principles, Law, and Practice, Oxford: Oxford University Press.

Nabhan, V. (2009), Study on Limitations and Exceptions for Copyright For Educational Purposes in the Arab Countries, Geneva: World Intellectual Property Organization.

Okediji, R. (2009), Toward an International Fair Use Doctrine, Columbia Journal of Transnational Law, 39, 75-175.

Ricketson, S. (1987), The Berne Convention for the Protection of Literary and Artistic Works: 1886-1986, London: University of London, and Kluwer.

U.S. Copyright Office (2014), Reproduction of Copyrighted Works by Educators and Librarians, (Circular 21), Washington, DC: Library of Congress.

UNESCO and WIPO (1976), Tunis Model Law on Copyright for Developing Countries, Geneva: UNESCO and WIPO.
WIPO Performances and Phonograms Treaty, December 20, 1996, S. Treaty Doc. No. 105-17, (1997) 36 I.L.M. 65; and c., December 20, 1996, S. Treaty Doc. No. 105-17, (1997) 36 I.L.M. 76

World Intellectual Property Organization (1971), Records of the Intellectual Property Conference of Stockholm: June 11 to July 14, 1967 Geneva: World Intellectual Property Organization.

World Intellectual Property Organization Copyright Treaty, December 20, 1996, S. Treaty Doc. No. 105-17, (1997) 36 I.L.M. 65 [cited as WCT]

Wright, R. (2009), The "Three-Step Test" and the Wider Public Interest: Towards a More Inclusive Interpretation, The Journal of World Intellectual Property, 12, 600-621. 